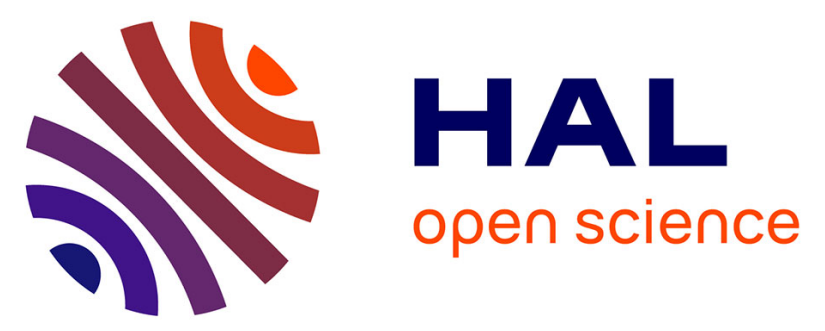

\title{
Effects of experimental warming, litter species, and presence of macroinvertebrates on litter decomposition and associated decomposers in a temperate mountain stream \\ Verónica Ferreira, Eric Chauvet, Cristina Canhoto
}

\section{To cite this version:}

Verónica Ferreira, Eric Chauvet, Cristina Canhoto. Effects of experimental warming, litter species, and presence of macroinvertebrates on litter decomposition and associated decomposers in a temperate mountain stream. Canadian Journal of Fisheries and Aquatic Sciences, 2014, vol. 72 (n²), pp. 206216. 10.1139/CJFAS-2014-0119 . hal-01142859

\section{HAL Id: hal-01142859 \\ https://hal.science/hal-01142859}

Submitted on 16 Apr 2015

HAL is a multi-disciplinary open access archive for the deposit and dissemination of scientific research documents, whether they are published or not. The documents may come from teaching and research institutions in France or abroad, or from public or private research centers.
L'archive ouverte pluridisciplinaire HAL, est destinée au dépôt et à la diffusion de documents scientifiques de niveau recherche, publiés ou non, émanant des établissements d'enseignement et de recherche français ou étrangers, des laboratoires publics ou privés. 


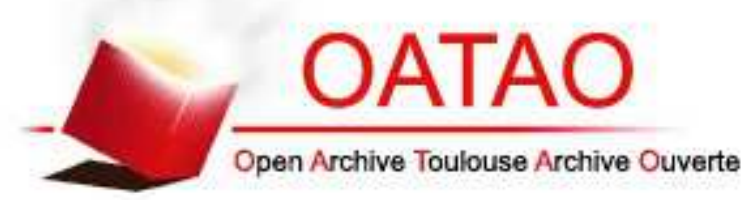

\section{Open Archive TOULOUSE Archive Ouverte (OATAO)}

OATAO is an open access repository that collects the work of Toulouse researchers and makes it freely available over the web where possible.

This is an author-deposited version published in : http://oatao.univ-toulouse.fr/ Eprints ID : 13699

To link to this article : DOI:10.1139/CJFAS-2014-0119

URL : http://dx.doi.org/10.1139/cjfas-2014-0119

To cite this version : Ferreira, Verónica and Chauvet, Eric and Canhoto, Cristina Effects of experimental warming, litter species, and presence of macroinvertebrates on litter decomposition and associated decomposers in a temperate mountain stream. (2014) Canadian Journal of Fisheries and Aquatic Sciences, vol. $72\left(\mathrm{n}^{\circ} 2\right)$. pp. 206-216. ISSN 0706-652X

Any correspondance concerning this service should be sent to the repository administrator: staff-oatao@ listes-diff.inp-toulouse.fr 


\title{
Effects of experimental warming, litter species, and presence of macroinvertebrates on litter decomposition and associated decomposers in a temperate mountain stream
}

\author{
Verónica Ferreira, Eric Chauvet, and Cristina Canhoto
}

\begin{abstract}
Small woodland streams make the majority of water courses in most watersheds. Litter decomposition is a key ecosystem process in these shaded streams, and its response to warming can have profound consequences for food webs and the carbon $(C)$ cycle. However, these responses can be modulated by litter identity and the structure of the detrital food web. Here we report on a manipulative study aiming at evaluating the effects of warming $\left(+2.8^{\circ} \mathrm{C}\right.$ ), litter identity (chestnut (Castanea sativa) or oak (Quercus robur) litter), and the structure of the detrital food web (presence or absence of macroinvertebrates) on litter decomposition and decomposers in a small, temperate woodland stream. Warming significantly stimulated overall (microbial-+ macroinvertebrate-driven) decomposition of oak and microbial-driven decomposition of chestnut. The similar shredder densities at elevated and ambient temperatures suggest that stimulated overall decomposition of oak resulted from increased activity of macroinvertebrate individuals. Stimulated microbial-driven decomposition of chestnut resulted from higher fungal activity with warming. Stimulation of litter decomposition by warming can lead to increases in the amount of $\mathrm{C}$ returned to the atmosphere and to a faster disappearance of litter from the benthos, with consequences to the $\mathrm{C}$ cycle and aquatic food webs.
\end{abstract}

Résumé : Les petits cours d'eau forestiers constituent la majeure partie des cours d'eau dans la plupart des bassins versants. La décomposition de la litière est un processus écosystémique clé dans ces cours d'eau ombragés, et sa réaction au réchauffement peut avoir de profondes répercussions sur les réseaux trophiques et le cycle du carbone (C). Ces réactions peuvent cependant être modulées par la nature de la litière et la structure du réseau trophique détritique. Nous rendons compte d'une étude reposant sur des manipulations visant à évaluer les effets du réchauffement $\left(+2,8^{\circ} \mathrm{C}\right)$, de la nature de la litière (litière de châtaignier (Castanea sativa) ou de chêne (Quercus robur)) et de la structure du réseau trophique détritique (présence ou absence de macroinvertébrés) sur la décomposition de la litière et les décomposeurs dans un petit cours d'eau forestier de région tempérée. Le réchauffement stimule significativement la décomposition globale (microbienne + par les macroinvertébrés) de la litière de chêne et la décomposition microbienne de la litière de châtaignier. Les densités semblables de déchiqueteurs à températures élevée et ambiante donnent à penser que la décomposition globale stimulée de la litière de chêne est le résultat de l'activité individuelle accrue de macroinvertébrés. La décomposition microbienne stimulée de litière de châtaignier résulte d'une augmentation de l'activité des micromycètes associée au réchauffement. La stimulation de la décomposition de la litière par le réchauffement peut mener à des augmentations de la quantité de $\mathrm{C}$ retourné à l'atmosphère et à la disparition plus rapide de litière du benthos, ce qui aurait des répercussions sur le cycle du $\mathrm{C}$ et les réseaux trophiques aquatiques. [Traduit par la Rédaction]

\section{Introduction}

Global mean air temperature is rising at an unprecedented rate, and models considering a doubling in atmospheric $\mathrm{CO}_{2}$ concentration predict a further increase by $1.5-4.5^{\circ} \mathrm{C}$ until the end of this century (IPCC 2013). This warming has the potential to affect species distribution, phenology (Parmesan and Yohe 2003), interactions (Traill et al. 2010), and biological activities (Brown et al. 2004), which can have important effects on biogeochemical cycles (e.g., the carbon (C) cycle). Fresh waters are not protected from this increase in temperature, since there is a direct relationship between water and air temperature (Pilgrim et al. 1998; Morrill et al. 2005). The majority of water courses in catchments in temperate regions are small, heterotrophic, woodland streams, where the decomposition of submerged litter is a key ecosystem process (Vannote et al. 1980; Allan and Castillo 2007). Since recent evidence suggests that fresh waters can contribute large amounts of
C to the atmosphere (Cole et al. 2007; Battin et al. 2008), it becomes urgent to understand how future warming will affect aquatic communities and the decomposition of terrestrial derived organic matter.

The decomposition of submerged organic matter, mostly leaf litter, is carried out by an array of organisms, mostly fungal decomposers and invertebrate shredders (Gessner et al. 1999). The response of these key players to warming will partially determine the dynamics of litter processing under future climate scenarios. Laboratory studies have shown that the activity of individual fungal and shredder species is stimulated by increases in temperature, until an optimum temperature is reached (Chauvet and Suberkropp 1998; González and Graça 2003; Dang et al. 2009), which can translate into accelerated litter decomposition (Ferreira and Chauvet 2011a, 2011b). These controlled and replicated experiments give useful insights into the mechanisms governing species activ-

V. Ferreira and C. Canhoto. IMAR (Institute of Marine Research), MARE (Marine and Environmental Sciences Centre), Department of Life Sciences, Faculty of Sciences and Technology, University of Coimbra, 3004-517 Coimbra, Portugal. E. Chauvet. Université de Toulouse; UPS, INPT; EcoLab (Laboratoire Ecologie Fonctionnelle et Environnement), 31062 Toulouse, France; CNRS (Centre national de la recherche scientifique); EcoLab; 31062, Toulouse, France.

Corresponding author: Verónica Ferreira (e-mail: veronica@ci.uc.pt). 
ities and ecosystem functioning; however, the generalization of these results to stream ecosystems is hindered by the small-scale and relative simplicity of the conditions simulated (Woodward et al. 2010).

Correlative studies over elevation (Fabre and Chauvet 1998; Taylor and Chauvet 2014), latitudinal (Irons et al. 1994; Boyero et al. 2011), and geothermal (Friberg et al. 2009) gradients have generally shown faster litter decomposition under higher temperatures. However, it is usually difficult in these studies to disentangle the effects of temperature from those associated with water chemistry and biogeography. Also, the temperature range addressed in these studies is often larger than the increase in temperature predicted by climate models (IPCC 2013). Therefore, the use of results observed over large natural thermal gradients to anticipate future effects of warming at a given location is not straightforward.

Our ability to predict the effects of increases in temperature on litter decomposition is complicated further by the possible interactions between warming and other factors (e.g., litter quality) on decomposers and detritivores (González and Graça 2003; Fernandes et al. 2012; Gonçalves et al. 2013). In temperate woodland streams, the autumnal leaf litter input often originates from multiple species that differ in leaf characteristics (Buzby and Perry 2000). Leaf litter identity (i.e., its physical and chemical characteristics) is known to affect microbial and invertebrate colonization and activity, with soft, high-quality (low $\mathrm{C}$ to nutrients ratio) litter being preferably colonized and faster decomposed than tough, low-quality litter (Gessner and Chauvet 1994; Canhoto and Graça 1996; Ferreira et al. 2012). In oligotrophic streams, warming might stimulate the decomposition of high-quality litter to a larger degree than that of low-quality litter, where microbial activity might be nutrient-limited (Thormann et al. 2004; Berbeco et al. 2012). On the other hand, the decomposition of tough litter might be stimulated by warming to a larger extent than that of soft litter, as it has been shown that the decomposition of lowquality litter is more temperature sensitive than that of highquality litter (Conant et al. 2008; Gonçalves et al. 2013).

The experimental manipulation of water temperature under natural field conditions would allow more realistic predictions of the effect of future climate warming on aquatic communities and on the functioning of headwaters, as it would allow to control for possible confounding factors of the temperature effect. This approach has obvious logistical constraints related with the continuous heating of flowing water, which explains why it has been undertaken only once, in early 1990s; at that time, however, only structural aspects of the macroinvertebrate community were assessed (Hogg et al. 1995; Hogg and Williams 1996).

In this study we used a stream manipulative experiment to assess the effect of an increase in water temperature by $2.8^{\circ} \mathrm{C}$ on the decomposition of submerged oak (Quercus robur) and chestnut (Castanea sativa) leaf litter, in the presence and absence of invertebrates. We anticipated that (i) warming would stimulate litter decomposition because of the temperature sensitivity of biological activities, (ii) stimulation would be stronger for the tougher litter because of higher temperature sensitivity of decomposition of poor quality litter (initial nitrogen concentration was similar for both litter species), and (iii) stimulation would be stronger in the presence of invertebrates that will take profit from enhanced microbial colonization. This experiment, however, was not replicated at the stream reach scale because of budget and logistical constrains, and, contrary to Hogg et al. (1995) and Hogg and Williams (1996), it lacked a before-after control-impact (BACI) design. Thus, this study has low statistical power and it is prone to type II errors.

\section{Materials and methods}

Experimental design and study site

Here we studied the individual and interactive effects of changes in water temperature and leaf litter species on microbialdriven and overall (microbial- + invertebrate-driven) litter decomposition. For this, leaves of oak and chestnut were incubated in fine and coarse mesh bags, over 2 months in winter (27 December 2011 - 25 February 2012), in both halves of a mountain stream reach that was divided longitudinally. One stream half was experimentally warmed by $2.8{ }^{\circ} \mathrm{C}$ above ambient water temperature (experimental half), while the other half served as control (control half). Warming was carried out from 28 October 2011 (i.e., 2 months before the study started) until the study ended. This experiment was not replicated at the stream reach level because of the elevated costs associated with continuously warming flowing water in the field and the difficulty in finding additional appropriate streams to manipulate (see below).

The study reach ( $\sim 1 \mathrm{~m}$ wide and $<10 \mathrm{~cm}$ deep) was located in Ribeira do Candal (Lousã Mountains, central Portugal; $40^{\circ} 4^{\prime} 44^{\prime \prime} \mathrm{N}$, $8^{\circ} 12^{\prime} 10^{\prime \prime} \mathrm{W}, 620 \mathrm{~m}$ above sea level), a second-order stream that drains an area of $0.8 \mathrm{~km}^{2}$ covered by mixed deciduous forest dominated by chestnut and oak and where human activity is low. The bedrock is schist and the stream substrate is composed of cobbles, pebbles, and sand. This stream was selected for this study because it meets a set of criteria needed to carry out the experimental warming: (i) it is a near-pristine stream that (ii) is relatively close to a small mountain village and (iii) is easily accessible.

The stream reach was divided longitudinally in half over a length of $22 \mathrm{~m}$ using schist stones, which penetrated the sediment $(<10 \mathrm{~cm}$ deep) and were cemented to the bedrock, preventing any transfer of water between stream halves. The water provided to the study reach was collected upstream and transported by gravity through pipes into two $260 \mathrm{~L}$ stainless steel tanks that delivered the water to both stream halves at $2.3 \mathrm{~L} \cdot \mathrm{s}^{-1}$ (Table 1) through two valves inserted in a dam constructed upstream the study reach. One of the tanks was equipped with heating resistors supplied by a constant $42 \mathrm{~kW}$, which warmed the water above ambient temperature. The target increase in water temperature was $3{ }^{\circ} \mathrm{C}$, based on predictions for air temperature in Portugal by the end of this century (Miranda et al. 2002) and on the relationship between water and air temperature reported for similar streams (Morrill et al. 2005). However, owing to electrical shutoffs during thunderstorms, the mean difference in temperature between the stream halves over the study period was $2.8^{\circ} \mathrm{C}$ (Table 1). A detailed description of the hydraulic and heating systems can be found in Canhoto et al. (2013).

\section{Water variables}

Water temperature was recorded hourly during the study period in both stream halves using submersed data loggers (Hobo Pendant UA-001-08, Onset Computer Corp., Massachusetts, USA). Hourly temperature records were averaged to produce daily means. Electrical conductivity (LF 330, WTW, Weilheim, Germany), pH (pH 3110, WTW, Weilheim, Germany), and dissolved oxygen (Oxi 3210, WTW, Weilheim, Germany) were recorded weekly in situ in both stream halves. At the same time, $300 \mathrm{~mL}$ of water were collected from each stream half, filtered through glass fiber filters (47 mm diameter, pore size $0.7 \mu \mathrm{m}$; Millipore APFF04700, Millipore Corp., Massachusetts, USA), transported on ice to the laboratory, and frozen until analyzed for nutrient concentrations. Nitrate, nitrite, and ammonium concentrations were determined by ionic chromatography (Dionex DX-120, Sunnyvale, California, USA), and soluble reactive phosphorus concentration was determined by the ascorbic acid method (APHA 1995). Alkalinity was determined by titration of $100 \mathrm{~mL}$ of stream water with sulfuric acid $0.01 \mathrm{~mol} \cdot \mathrm{L}^{-1}$ to an endpoint of $\mathrm{pH} 4.2$ (APHA 1995). Discharge 
Table 1. Water variables in the control and experimental half during the study period (27 December 2011 - 25 February 2012).

\begin{tabular}{lrccr}
\hline Water variable & \multicolumn{1}{c}{$\begin{array}{l}\text { Control } \\
\text { half }\end{array}$} & \multicolumn{1}{l}{$\begin{array}{l}\text { Experimental } \\
\text { half }\end{array}$} & \multicolumn{1}{c}{$P$} \\
\hline Temperature $\left({ }^{\circ} \mathrm{C}\right)$ & 60 & $6.4 \pm 1.2$ & $9.2 \pm 2.4$ & $<0.001$ \\
Discharge $\left(\mathrm{L} \cdot \mathrm{s}^{-1}\right)$ & 9 & $2.3 \pm 0.1$ & $2.3 \pm 0.1$ & 0.327 \\
Conductivity $\left(\mu \mathrm{S} \cdot \mathrm{cm}^{-1}\right)$ & 10 & $26.3 \pm 0.2$ & $26.4 \pm 0.2$ & 0.018 \\
DO $\left(\mathrm{mg} \cdot \mathrm{L}^{-1}\right)$ & 10 & $12.2 \pm 0.7$ & $11.4 \pm 0.8$ & $<0.001$ \\
DO $(\%)$ & 10 & $105.9 \pm 3.4$ & $106.0 \pm 3.4$ & 0.846 \\
pH & 10 & $7.4 \pm 0.2$ & $7.3 \pm 0.2$ & 0.051 \\
Alkalinity & 6 & $7.3 \pm 0.8$ & $7.8 \pm 0.9$ & 0.178 \\
$\quad\left(\mathrm{mg} \mathrm{CaCO}{ }_{3} \cdot \mathrm{L}^{-1}\right)$ & & & & \\
$\mathrm{NO}_{3}\left(\mu \mathrm{g} \cdot \mathrm{L}^{-1}\right)$ & 11 & $88.2 \pm 23.6$ & $108.3 \pm 17.1$ & 0.163 \\
$\mathrm{SRP}\left(\mu \mathrm{g} \cdot \mathrm{L}^{-1}\right)$ & 9 & $2.5 \pm 5.6$ & $0.8 \pm 1.8$ & 0.277 \\
\hline
\end{tabular}

Note: Temperature: mean daily temperature; DO: dissolved oxygen; SRP: soluble reactive phosphorus; $n$ : number of measurements. Nitrite and ammonium were below detection limits $\left(<100\right.$ and $<50 \mu \mathrm{g} \cdot \mathrm{L}^{-1}$, respectively). Values are means \pm SD. Comparisons between stream halves were made by two-tail paired $t$ tests; $P$ values are given.

was determined volumetrically at the output of the valves that delivered water to each stream half (Gore 1996).

\section{Leaf litter bags and decomposition}

Leaves were collected just after abscission in Lousã Mountains (oak, autumn 2006) and Margaraça forest (chestnut, autumn 2007), central Portugal, air-dried at room temperature, and stored in the dark until used. Batches of air-dried leaves (2.25-2.54 g; approximately five leaves per bag) were moisten with distilled water to render them soft and less susceptible to breakage due to handling and enclosed in fine mesh $(10 \mathrm{~cm} \times 12 \mathrm{~cm}, 0.5 \mathrm{~mm}$ mesh) and in coarse mesh bags $(10 \mathrm{~cm} \times 12 \mathrm{~cm}, 10 \mathrm{~mm}$ mesh). Fine mesh bags exclude macroinvertebrates, and thus litter decomposition is mainly carried out by the microbial community, while coarse mesh bags allow macroinvertebrates to enter, and thus litter decomposition is driven by the combined activities of macroinvertebrates and microbes. Litter in coarse mesh bags is also susceptible to mass loss owing to physical fragmentation; how ever, this was likely negligible in our case, as current velocity was low $\left(\sim 0.05 \mathrm{~m} \mathrm{~s}^{-1}\right.$; Ferreira et al. 2006). Nine litter bags of each litter species and mesh size were deployed in each stream half on 27 December 2011. On the same day, three extra litter bags for each litter species and mesh size were taken to the field, submerged for $\sim 10 \mathrm{~min}$, returned to the laboratory, oven-dried at $105{ }^{\circ} \mathrm{C}$ for $48 \mathrm{~h}$, weighed $( \pm 0.1 \mathrm{mg})$, and grinded $(<500 \mu \mathrm{m}$ powder size; ZM 100, Retsch, Haan, Germany). A subsample of litter powder was oven-dried at $105^{\circ} \mathrm{C}$ for $48 \mathrm{~h}$, weighed $( \pm 0.1 \mathrm{mg})$, ignited at $550{ }^{\circ} \mathrm{C}$ for $4 \mathrm{~h}$, and reweighed $( \pm 0.1 \mathrm{mg})$ to allow calculation of the ash fraction and the initial ash-free dry mass (AFDM), taking into account mass loss due to handling.

Three replicate litter bags per date were sampled after 11, 20, and 60 days of incubation, placed individually in zip-lock bags, transported to the laboratory in a cooler, and promptly processed. In the laboratory, leaves from fine mesh bags were gently rinsed with distilled water, and two sets of five leaf discs were removed with a cork borer (12 $\mathrm{mm}$ diameter) for microbial determinations (see below). Leaves from coarse mesh bags were rinsed with tap water over a $500 \mu \mathrm{m}$ mesh sieve, and the macroinvertebrates retained were recovered (see below). The remaining litter was oven-dried, weighed, and grinded. A subsample of litter powder was oven-dried, weighed, ignited, and reweighed (as above) to allow calculation of the ash fraction and the AFDM remaining (after correction for the mass of discs removed from fine mesh bags). Results were expressed as AFDM remaining at each sampling date (\%). Extra subsamples of litter powder from fine mesh bags were used for chemical determinations (see below).
Litter chemical composition and toughness

Oven-dried $\left(105^{\circ} \mathrm{C}, 48 \mathrm{~h}\right)$ subsamples of litter powder $(<500 \mu \mathrm{m}$ size) from day 0 and from fine mesh bags retrieved from the stream were weighed (3.32-4.57 $\mathrm{mg}$ ) and used for determination of phosphorus $(\mathrm{P})$ concentration. Phosphorus was extracted from litter by incubation with sodium persulphate and sodium hydroxide in the autoclave at $120^{\circ} \mathrm{C}$ for $2 \mathrm{~h}$. The $\mathrm{pH}$ of the suspension was raised to $\sim 4$ units with sodium hydroxide, an aliquot was filtered through syringe filters (pore size $0.2 \mu \mathrm{m}$; Minisart, Sartorius, Goettingen, Germany), and the P concentration in the solution was determined by the ascorbic acid method (APHA 1995). For the same samples, litter powder (0.50-0.72 mg) was used for determination of nitrogen $(\mathrm{N})$ concentrations by an auto analyzer (IRMS Thermo Delta V Advantage with a Flash EA, 1112 series). Results were expressed as \% $\mathrm{P}$ and \% $\mathrm{N}$ of dry mass (DM).

Initial leaf toughness was determined for 10 leaves of each species using a penetrometer (Graça et al. 2005). Leaves were soaked in tap water for $6 \mathrm{~h}$, immobilized between two acrylic sheets, and the mass required to force a $0.49 \mathrm{~mm}^{2}$ iron rod through the leaf (avoiding primary and secondary veins and keeping the upper leaf blade facing up) was quantified (three times per leaf). Results were expressed as grams.

\section{Fungal biomass and conidial production}

One set of five leaf discs (usually one disc per leaf) taken from fine mesh bags was used for determination of ergosterol concentration, as a proxy of fungal biomass (Graça et al. 2005). Leaf discs were frozen at $-20{ }^{\circ} \mathrm{C}$ until ergosterol extraction, freeze-dried overnight (LY3TTE, Snijders Scientific, Tilburg, Netherlands), weighed $( \pm 0.1 \mathrm{mg})$ to determine disc DM, and placed in tightly closed tubes with alkaline methanol $\left(8 \mathrm{~g} \mathrm{KOH} \cdot \mathrm{L}^{-1}\right)$. Lipids were extracted in a water bath at $80^{\circ} \mathrm{C}$ for $30 \mathrm{~min}$. The extract was then purified by solid-phase extraction (Oasis HLB cartridge, barrel size $3 \mathrm{~cm}^{3}$, particle size $30 \mu \mathrm{m}$, pore size $80 \AA$; Waters Corp., Massachusetts, USA) (Graça et al. 2005). Ergosterol was quantified by high-performance liquid chromatography (HPLC) by measuring absorbance at $282 \mathrm{~nm}$. The HPLC system (Dionex DX-120, Sunnyvale, California, USA) was equipped with the LiChroCART 250-4 LiChrospher 100 RP-18 (5 $\mu \mathrm{m}$ ) column (Merck, Darmstadt, Germany) and maintained at $33{ }^{\circ} \mathrm{C}$. The mobile phase was $100 \%$ methanol, flowing at $1.4 \mathrm{~mL} \cdot \mathrm{min}^{-1}$. Ergosterol was converted into mycelial biomass assuming $5.5 \mu \mathrm{g}$ ergosterol.(mg mycelial DM) ${ }^{-1}$ (Gessner and Chauvet 1993). Discs' DM were converted into AFDM using the ash fraction derived from the discs used for sporulation (see below), and results were expressed as milligrams mycelial biomass per gram leaf litter AFDM.

The second set of five leaf discs (usually one disc per leaf) taken from fine mesh bags was used to induce sporulation by aquatic hyphomycetes. Leaf discs were incubated in $100 \mathrm{~mL}$ Erlenmeyer flasks with $25 \mathrm{~mL}$ of filtered stream water from the corresponding stream half (47 $\mathrm{mm}$ diameter, pore size $0.7 \mu \mathrm{m}$; Millipore APFF04700, Millipore Corp., Massachusetts, USA). Incubations took place over $48 \mathrm{~h}$ in an orbital shaker $\left(100 \mathrm{r} \cdot \mathrm{min}^{-1}\right)$ placed in a room at $15^{\circ} \mathrm{C}$ and with a $12 \mathrm{~h}$ light : $12 \mathrm{~h}$ dark photoperiod. Logistic constraints prevented sporulation from being induced at the temperature observed in each stream half on the sampling date, which would allow assessing the direct effect of temperature on conidial production. However, inducing fungal sporulation from litter retrieved from both stream halves at the same temperature permitted the assessment of differences in conidial production that are due to differences in the number of conidiophores on the surface of decomposing litter induced by differences in temperature during the incubation in the field. The conidial suspensions were poured into $50 \mathrm{~mL}$ Falcon tubes, fixed with $2 \mathrm{~mL}$ of $37 \%$ formalin, and the final volume adjusted to $35 \mathrm{~mL}$ with distilled water. The remaining leaf discs were oven-dried, weighed, ignited, and reweighed as above to calculate the discs' ash fraction and AFDM. 
When preparing filters for conidia counting and identification, $150 \mu \mathrm{L}$ Triton X-100 (0.5\%) were added to the suspension and mixed with a magnetic stirring bar to ensure a uniform distribution of conidia, and 1-5 $\mathrm{mL}$ of the suspension were filtered $(2.5 \mathrm{~mm}$ diameter, pore size $5 \mu \mathrm{m}$; Millipore SMWP, Millipore Corp.). Filters were stained with $0.05 \%$ trypan blue in $60 \%$ lactic acid, and spores were identified and counted under a compound microscope at 320x magnification (Graça et al. 2005). Sporulation rates were expressed as number of conidia per milligram leaf litter AFDM per day, and species richness was expressed as number of taxa per sample.

\section{Macroinvertebrates}

Macroinvertebrates $(>500 \mu \mathrm{m})$ retrieved from coarse mesh bags were preserved in $96 \%$ ethanol. Individuals were counted, and the shredders were identified to the lowest possible taxonomic level (generally genus or species) following Tachet et al. (2010). Abundance was expressed as total number of invertebrates per gram leaf litter AFDM and number of shredders per gram leaf litter AFDM. Shredder richness was expressed as number of taxa per sample.

\section{Data analysis}

Water variables were compared between stream halves by twotail paired $t$ tests. Exponential decomposition rates $\left(k\right.$ day $\left.^{-1}\right)$ were calculated as the slope of linear regression of the ln-transformed fraction of AFDM remaining over time (days), with the intercept fixed at 0 . Proportion of litter mass remaining (ln-transformed) was compared between stream halves (control versus experimental), litter species (oak versus chestnut), and mesh sizes (coarse versus fine) by repeated measures ANOVA (RM ANOVA), with sampling date as the within-subjects factor and stream half, litter species, and mesh size as the between-subjects factors. Post hoc multiple comparisons were made with Fisher's least significant difference test (Statistica 7 software; StatSoft Inc., Tulsa, Oklahoma, USA).

The sensitivities to temperature of decomposition rates were calculated as $Q_{10-q}$ values: $Q_{10-q}=\left(t_{1} / t_{\mathrm{h}}\right)^{\left[10 /\left(T_{\mathrm{h}}-T_{1}\right)\right]}$, where $t_{1}$ and $t_{\mathrm{h}}$ are the time (days) to decompose 50\% AFDM at the lower and higher temperature, respectively, $T_{1}$ is the lower temperature (mean temperature over the incubation period in the control half $=6.4^{\circ} \mathrm{C}$ ), and $T_{h}$ is the higher temperature (mean temperature over the incubation period in the experimental half $\left.=9.2^{\circ} \mathrm{C}\right)($ Conant et al 2008). The time to decompose $50 \%$ initial AFDM under $10{ }^{\circ} \mathrm{C}$ warming was calculated as follows: time (days) to decompose $50 \%$ initial AFDM under ambient temperature $/ Q_{10-q}$.

Litter initial $\mathrm{P}$ and $\mathrm{N}$ concentrations and leaf toughness were compared between species by two-tail $t$ tests. Dynamics of nutrients concentration, fungal biomass concentration $(\log (x)$-transformed) sporulation rate by aquatic hyphomycetes, fungal species richness, total macroinvertebrate abundance $(\log (x+1)$-transformed), shredder abundance $(\log (x+1)$-transformed $)$, and shredder taxa richness $(\log (x+1)$-transformed) were compared between stream halves (control versus experimental) and litter species (oak versus chestnut) by RM ANOVA, with sampling date as the withinsubjects factor and stream half and litter species as the betweensubjects factors. Data transformation was carried out when necessary to achieve normality (checked by Shapiro-Wilk's test) and homoscedasticity (checked by the Bartlett $\chi^{2}$ test). Fisher's least significant difference test was used for multiple comparisons when the RM ANOVAs detected an effect of stream half, litter species, or their interaction in the above-mentioned variables (Statistica 7 software).

Overall differences in aquatic hyphomycete and shredder communities among treatments were assessed by analyses of similarity (ANOSIM) based on Bray-Curtis similarity matrix of abundance $(\log (x+1)$-transformed) of conidia and shredder indi-
Fig. 1. Decomposition rates of oak and chestnut leaf litter, incubated in fine mesh (FM) and coarse mesh bags (CM) in the control (Cont) and experimental (Exp) stream half over 60 days. Values are means \pm SE. Treatments were compared by RM ANOVA; treatments with the same letter do not significantly differ (Fisher's test, $P>0.050$ ).

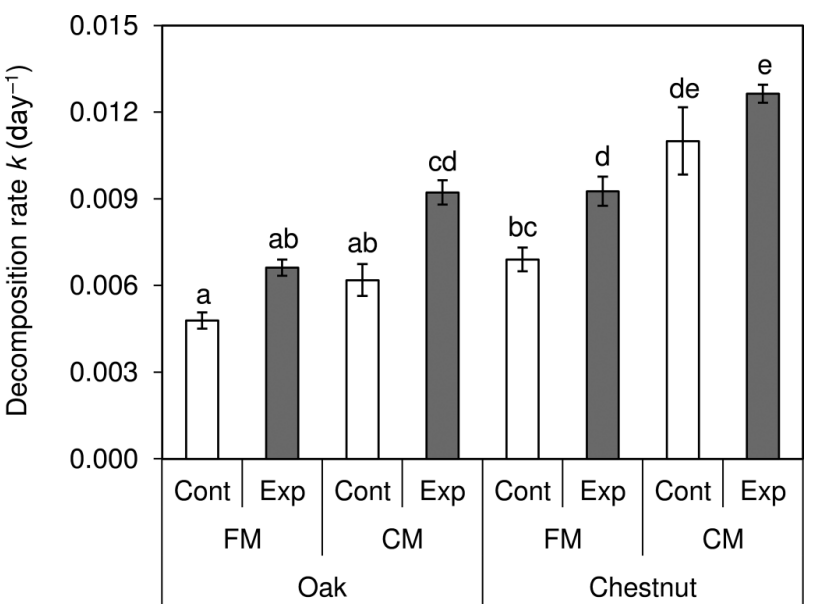

viduals, respectively (Primer 6 software, Primer-E Ltd, Plymouth, UK).

\section{Results}

\section{Water variables}

The experimental warming successfully increased the water temperature of the experimental half by an average of $2.8{ }^{\circ} \mathrm{C}$ above the temperature observed in the control half during the study period (paired $t$ test, $P<0.001$; Table 1 ). This resulted in daily thermal sums of 388 and $560{ }^{\circ} \mathrm{C}$ by day 60 for the control and experimental half, respectively.

During the study period, stream water had low conductivity and alkalinity and was well oxygenated, circumneutral, and nutrient-poor (Table 1). Significant differences between stream halves were found only for conductivity $\left(26.3 \mu \mathrm{S} \cdot \mathrm{cm}^{-1}\right.$ in the control half versus $26.4 \mu \mathrm{S} \cdot \mathrm{cm}^{-1}$ in the experimental half; paired $t$ test, $P=0.018$ ) and for dissolved oxygen concentration $\left(12.2 \mathrm{mg} \cdot \mathrm{L}^{-1}\right.$ in the control half versus $11.4 \mathrm{mg} \cdot \mathrm{L}^{-1}$ in the experimental half; $P<0.001$ ), as expected, owing to differences in temperature (Table 1 ).

\section{Leaf litter decomposition}

Litter mass loss over the 60-day incubation period varied between $24 \%$ and $47 \%$ of initial AFDM across treatments, and the dynamics of litter decomposition fitted the negative exponential model well $\left(0.73<R^{2}<0.99, P<0.001\right.$ for all treatments $)$. This translated into decomposition rates between 0.0048 and 0.0126 day $^{-1}$ across treatments (Fig. 1). Chestnut leaf litter decomposed $37 \%-78 \%$ faster than oak leaf litter, which resulted in significant differences in decomposition rates between litter species (RM ANOVA, $P<0.001$ for litter species; Table 2 ) in both stream halves and mesh sizes (Fisher's test, $P<0.030$; Fig. 1). Litter enclosed in coarse mesh bags decomposed 29\%-59\% faster than litter enclosed in fine mesh bags (RM ANOVA, $P<0.001$ for mesh size; Table 2), which nevertheless suggests the small contribution of shredders to the overall litter decomposition (23\%-37\% versus $63 \%-77 \%$ of microbes). This resulted in significant differences in decomposition rates between mesh sizes for oak incubated in the experimental stream half (Fisher's test, $P=0.024$ ) and for chestnut incubated in the control $(P=0.003)$ and in the experimental halves $(P=0.017)$; the decomposition rate of oak litter in the control 
Table 2. Summary table for RM ANOVA performed on proportion of litter mass remaining (ln-transformed) of oak and chestnut leaf litter incubated in coarse and fine mesh bags in the control and experimental half over 60 days.

\begin{tabular}{lrrr}
\hline Source of variation & df & $F$ & $P$ \\
\hline Intercept & 1 & 1252.118 & $<0.001$ \\
Stream half & 1 & 19.319 & $<0.001$ \\
Litter species & 1 & 40.772 & $<0.001$ \\
Mesh size & 1 & 26.473 & $<0.001$ \\
Stream half $\times$ litter species & 1 & 0.044 & 0.837 \\
Stream half $\times$ mesh size & 1 & 0.001 & 0.976 \\
Litter species $\times$ mesh size & 1 & 1.007 & 0.331 \\
Stream half $\times$ litter species $\times$ mesh size & 1 & 0.688 & 0.419 \\
Error & 16 & & \\
Time & 2 & 226.417 & $<0.001$ \\
Time $\times$ stream half & 2 & 5.378 & 0.010 \\
Time $\times$ litter species & 2 & 11.997 & $<0.001$ \\
Time $\times$ mesh size & 2 & 12.718 & $<0.001$ \\
Time $\times$ stream half $\times$ litter species & 2 & 0.332 & 0.720 \\
Time $\times$ stream half $\times$ mesh size & 2 & 0.108 & 0.898 \\
Time $\times$ Litter species $\times$ mesh size & 2 & 2.759 & 0.078 \\
Time $\times$ stream half $\times$ litter species $\times$ mesh size & 2 & 0.402 & 0.673 \\
Error & 32 & & \\
\hline
\end{tabular}

stream half did not significantly differ between mesh sizes $(P=0.120$; Fig. 1). Litter incubated in the experimental half decomposed 15\%-49\% faster than litter incubated in the control half (RM ANOVA, $P<0.001$ for stream half; Table 2), but significant differences between stream halves were found only for oak in coarse mesh bags (Fisher's test, $P=0.01$ ) and for chestnut in fine mesh bags $(P=0.024$; Fig. 1$)$.

The temperature sensitivity of litter decomposition was higher for oak than for chestnut in both mesh sizes. However, the temperature sensitivity of oak decomposition was higher in coarse than in fine mesh bags, while the opposite pattern was observed for chestnut (Table 3). When considering a $10{ }^{\circ} \mathrm{C}$ increase in temperature, however, both litter species decompose at similar rates (Table 3).

\section{Litter chemical composition and toughness}

Leaf litter species differed in initial chemical quality and toughness. Initial P concentration was 3.6-fold higher in oak than in chestnut ( $t$ test, $P<0.001$ ), although both concentrations were very high $(0.45 \% \pm 0.02 \% \mathrm{DM}$ (mean $\pm \mathrm{SE})$ and $0.12 \% \pm 0.01 \% \mathrm{DM}$, respectively). Initial $\mathrm{N}$ concentration did not significantly differ between litter species $(0.98 \% \pm 0.06 \%$ for oak and $0.96 \% \pm 0.04 \%$ for chestnut; $t$ test, $P=0.825)$. Initial leaf toughness was significantly higher for oak $(95.46 \pm 6.60 \mathrm{~g})$ than for chestnut $(64.21 \pm 4.48 \mathrm{~g}$; $t$ test, $P=0.001$ ).

Once in water, $\mathrm{P}$ leached rapidly from the litter, and after 11 days both litter species in both stream halves had $0.05 \% \mathrm{P}$, which increased similarly across treatments (50\%-77\%) over the incubation period (RM ANOVA, $P<0.001$ for time; Table 4; Fig. $2 a$ ). $P$ concentration did not significantly differ between litter species (RM ANOVA, $P=0.636$ for litter species) or temperature regimes $(P=0.237$ for stream half; Table 4$) . N$ concentration increased across treatments (42\%-63\%) over the incubation period (RM ANOVA, $P<0.001$ for time; Table 4 ). The $\mathrm{N}$ concentration associated with chestnut in the experimental stream half was the highest across treatments (Fisher's test, $P<0.043$; Fig. $2 b$ ).

\section{Fungal biomass and conidial production}

Maximum fungal biomass concentration on decomposing litter was recorded by the last sampling date (130-251 mg.(g AFDM) $\left.{ }^{-1}\right)$ (RM ANOVA, $P=0.001$ for time; Table 5; Fig. $3 a$ ). Fungal biomass accrual was higher for chestnut than for oak in both stream halves (RM ANOVA, $P<0.001$ for litter species), while there was no
Table 3. Temperature sensitivities $\left(Q_{10-q}\right)$ of litter decomposition and time to decompose $50 \%$ initial AFDM under $10{ }^{\circ} \mathrm{C}$ warming for oak and chestnut incubated in fine and coarse mesh bags.

\begin{tabular}{llll}
\hline Litter species & Mesh size & $Q_{10-q}$ & Time (days) \\
\hline Oak & Fine & 3.18 & 46 \\
\multirow{2}{*}{ Chestnut } & Coarse & 4.15 & 27 \\
& Fine & 2.86 & 35 \\
& Coarse & 1.64 & 38 \\
\hline
\end{tabular}

Table 4. Summary table for RM ANOVAs performed on phosphorus (P) and nitrogen $(\mathrm{N})$ concentrations in oak and chestnut leaf litter incubated in fine mesh bags in the control and experimental half over 60 days.

\begin{tabular}{|c|c|c|c|c|c|}
\hline \multirow[b]{2}{*}{ Source of variation } & \multirow[b]{2}{*}{ df } & \multicolumn{2}{|l|}{$\mathrm{P}$} & \multicolumn{2}{|l|}{$\mathrm{N}$} \\
\hline & & F & $P$ & F & $P$ \\
\hline Intercept & 1 & 1102.651 & $<0.001$ & 3794.213 & $<0.001$ \\
\hline Stream half & 1 & 1.129 & 0.319 & 5.529 & 0.047 \\
\hline Litter species & 1 & 0.177 & 0.685 & 5.194 & 0.052 \\
\hline Stream half $\times$ litter species & 1 & 0.169 & 0.691 & 1.262 & 0.294 \\
\hline Error & 8 & & & & \\
\hline Time & 2 & 31.481 & $<0.001$ & 37.015 & $<0.001$ \\
\hline Time $\times$ stream half & 2 & 0.649 & 0.536 & 0.059 & 0.942 \\
\hline Time $\times$ litter species & 2 & 0.332 & 0.722 & 2.576 & 0.107 \\
\hline $\begin{array}{l}\text { Time } \times \text { stream half } \times \text { litter } \\
\text { species }\end{array}$ & 2 & 2.016 & 0.166 & 1.365 & 0.284 \\
\hline Error & 16 & & & & \\
\hline
\end{tabular}

Fig. 2. (a) Phosphorus (P) and (b) nitrogen (N) concentrations in oak and chestnut leaf litter incubated in fine mesh bags in the control and experimental half over 60 days. Values are means \pm SE. SE bars may be smaller than the symbols.
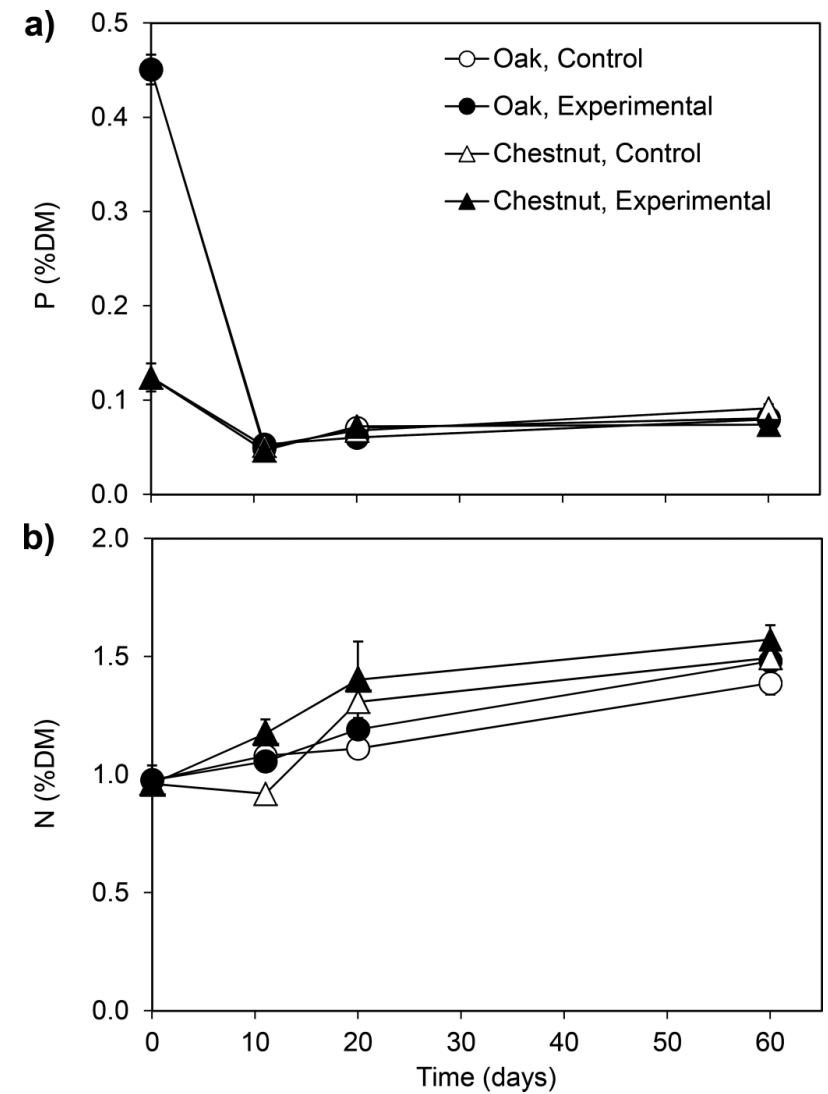
Table 5. Summary table for RM ANOVAs performed on fungal biomass concentration $(\log (x)$ transformed), sporulation rates, and fungal species richness associated with oak and chestnut leaf litter incubated in fine mesh bags in the control and experimental half over 60 days.

\begin{tabular}{|c|c|c|c|c|c|c|c|}
\hline \multirow[b]{2}{*}{ Source of variation } & \multirow[b]{2}{*}{ df } & \multicolumn{2}{|c|}{ Fungal biomass } & \multicolumn{2}{|c|}{$\begin{array}{l}\text { Sporulation } \\
\text { rate }\end{array}$} & \multicolumn{2}{|c|}{ Species richness } \\
\hline & & F & $P$ & F & $P$ & F & $P$ \\
\hline Intercept & 1 & 12920.456 & $<0.001$ & 97.442 & $<0.001$ & 406.125 & $<0.001$ \\
\hline Stream half & 1 & 0.461 & 0.516 & 4.951 & 0.057 & 0.014 & 0.909 \\
\hline Litter species & 1 & 76.772 & $<0.001$ & 8.977 & 0.017 & 0.681 & 0.433 \\
\hline Stream half $\times$ litter species & 1 & 2.157 & 0.180 & 3.629 & 0.093 & 0.347 & 0.572 \\
\hline Error & 8 & & & & & & \\
\hline Time & 2 & 11.503 & 0.001 & 30.318 & $<0.001$ & 9.418 & 0.002 \\
\hline Time $\times$ stream half & 2 & 4.577 & 0.027 & 2.363 & 0.126 & 0.085 & 0.919 \\
\hline Time $\times$ litter species & 2 & 3.123 & 0.072 & 12.631 & 0.001 & 0.012 & 0.988 \\
\hline Time $\times$ stream half $\times$ litter species & 2 & 0.269 & 0.767 & 4.517 & 0.028 & 0.521 & 0.604 \\
\hline Error & 16 & & & & & & \\
\hline
\end{tabular}

Fig. 3. (a) Fungal biomass concentration, (b) sporulation rates, and (c) species richness of aquatic hyphomycetes associated with oak and chestnut leaf litter incubated in fine mesh bags in the control and experimental half over 60 days. Values are means \pm SE.
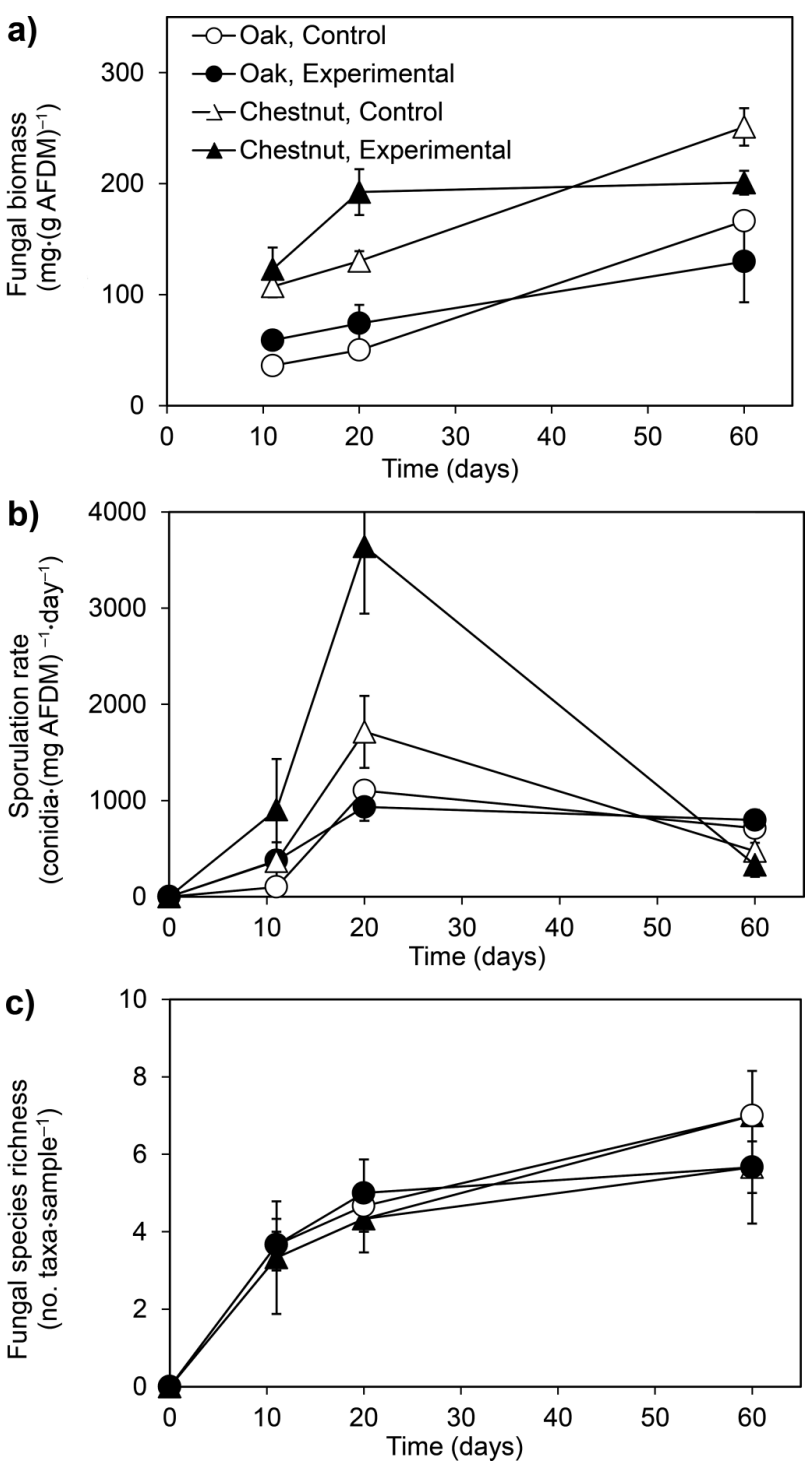

significant difference between stream halves for any litter species (RM ANOVA, $P=0.516$ for stream half; Table 5; Fig. $3 a$ ).

Sporulation by aquatic hyphomycetes increased until day 20 , when the maximum sporulation rate varied between 932 and 3642 conidia $\cdot(\mathrm{mg} \mathrm{AFDM})^{-1} \cdot$ day $^{-1}$ across treatments, decreasing afterwards (RM ANOVA, $P<0.001$ for time; Table 5; Fig. 3b). The sporulation rate associated with chestnut incubated in the experimental half was the highest across treatments (Fisher's test, $P<0.019$; Fig. $3 b)$. Aquatic hyphomycetes species richness increased over time (RM ANOVA, $P=0.002$ for time; Table 5; Fig. 3c), but no significant difference was found among treatments (RM ANOVA, $P=0.433$ for litter species and 0.909 for stream half; Table 5).

The aquatic hyphomycete community structure varied greatly over time (ANOSIM, global $R=0.724, P=0.001$; Fig. 4). Early communities were dominated by Tetrachaetum elegans (57\%-91\%). Flagellospora curvula also had important contribution (3\%-37\%) until day 20 , after which its contribution decreased to $<1 \%$. The relative abundances of Anguillospora filiformis, Articulospora tetracladia, and Tricladium chaetocladium increased from $<4 \%$ at day 11 to $8 \%$ $36 \%$ at day 60 , when they co-dominated with T. elegans $(22 \%-43 \%$; Fig. 4). Litter species also contributed to shape fungal communities (ANOSIM, global $R=0.147, P=0.013$ ), which can be explained by the presence of Heliscus lugdunensis and Tricladium splendens only in oak and of Alatospora acuminata and Dendrospora erecta only in chestnut. Clavatospora longibrachiata was also more represented in oak than in chestnut. Water temperature did not seem to have any significant role in shaping fungal communities (ANOSIM, global $R=0.038, P=0.271$.

\section{Macroinvertebrates}

Maximum abundance of total macroinvertebrates was found at the last sampling date (22-46 individuals·(g AFDM) $\left.{ }^{-1}\right)$, except for oak incubated in the experimental half where abundance peaked at day 20 (16 individuals. $\left.(\mathrm{g} A F D M)^{-1}\right)($ RM ANOVA, $P=0.026$ for time; Table 6; Fig. 5a). There was, however, no significant effect of litter species or water temperature on total macroinvertebrate abundance (RM ANOVA, $P=0.142$ for litter species and 0.811 for stream half; Table 6).

The percentage of shredder individuals colonizing decomposing litter varied between $0 \%$ and $25 \%$ across treatments and dates. Shredder abundance was low across treatments $\left.(<7 \text { individuals.(g AFDM })^{-1}\right)$, it did not vary much over time (RM ANOVA, $P=0.441$ for time), but it was significantly higher in chestnut incubated in the control half than in the other three treatments (Fisher's test, $P<0.009$; Table 6; Fig. $5 b$ ). Shredder taxa richness was low ( $<3$ taxa.sample ${ }^{-1}$; total of nine species) and did not vary much over time because of high variability (RM ANOVA $P=0.530$ for time). Shredder richness was significantly higher in 
Table 6. Summary table for RM ANOVAs performed on total macroinvertebrate abundance $(\log (x+1)$-transformed), shredder abundance $(\log (x+1)$-transformed), and shredder taxa richness $(\log (x+1)$-transformed) associated with oak and chestnut leaf litter incubated in coarse mesh bags in the control and experimental half over 60 days.

\begin{tabular}{|c|c|c|c|c|c|c|c|}
\hline \multirow[b]{2}{*}{ Source of variation } & \multirow[b]{2}{*}{ df } & \multicolumn{2}{|c|}{ Total abundance } & \multicolumn{2}{|c|}{$\begin{array}{l}\text { Shredder } \\
\text { abundance }\end{array}$} & \multicolumn{2}{|c|}{ Taxa richness } \\
\hline & & $F$ & $P$ & $F$ & $P$ & $F$ & $P$ \\
\hline Intercept & 1 & 929.394 & $<0.001$ & 74.740 & $<0.001$ & 63.740 & $<0.001$ \\
\hline Stream half & 1 & 0.061 & 0.811 & 9.418 & 0.015 & 6.068 & 0.039 \\
\hline Litter species & 1 & 2.656 & 0.142 & 18.822 & 0.002 & 10.527 & 0.012 \\
\hline Stream half $\times$ litter species & 1 & 0.453 & 0.520 & 3.048 & 0.119 & 1.074 & 0.330 \\
\hline Error & 8 & & & & & & \\
\hline Time & 2 & 4.651 & 0.026 & 0.861 & 0.441 & 0.661 & 0.530 \\
\hline Time $\times$ stream half & 2 & 4.890 & 0.022 & 1.117 & 0.351 & 1.464 & 0.261 \\
\hline Time $\times$ litter species & 2 & 0.284 & 0.756 & 0.334 & 0.721 & 1.941 & 0.176 \\
\hline Time $\times$ stream half $\times$ litter species & 2 & 0.070 & 0.932 & 0.762 & 0.483 & 0.283 & 0.757 \\
\hline Error & 16 & & & & & & \\
\hline
\end{tabular}

Fig. 4. Relative contribution of aquatic hyphomycete species to the total conidial production associated with $(a)$ oak and $(b)$ chestnut leaf litter incubated in fine mesh bags in the control (Cont) and experimental (Exp) half over 60 days. Species contributing with a minimum of $5 \%$ conidia at least once are depicted. The remaining eight rare species are shown together as "Others", with a combined maximum contribution of 5.05\%.
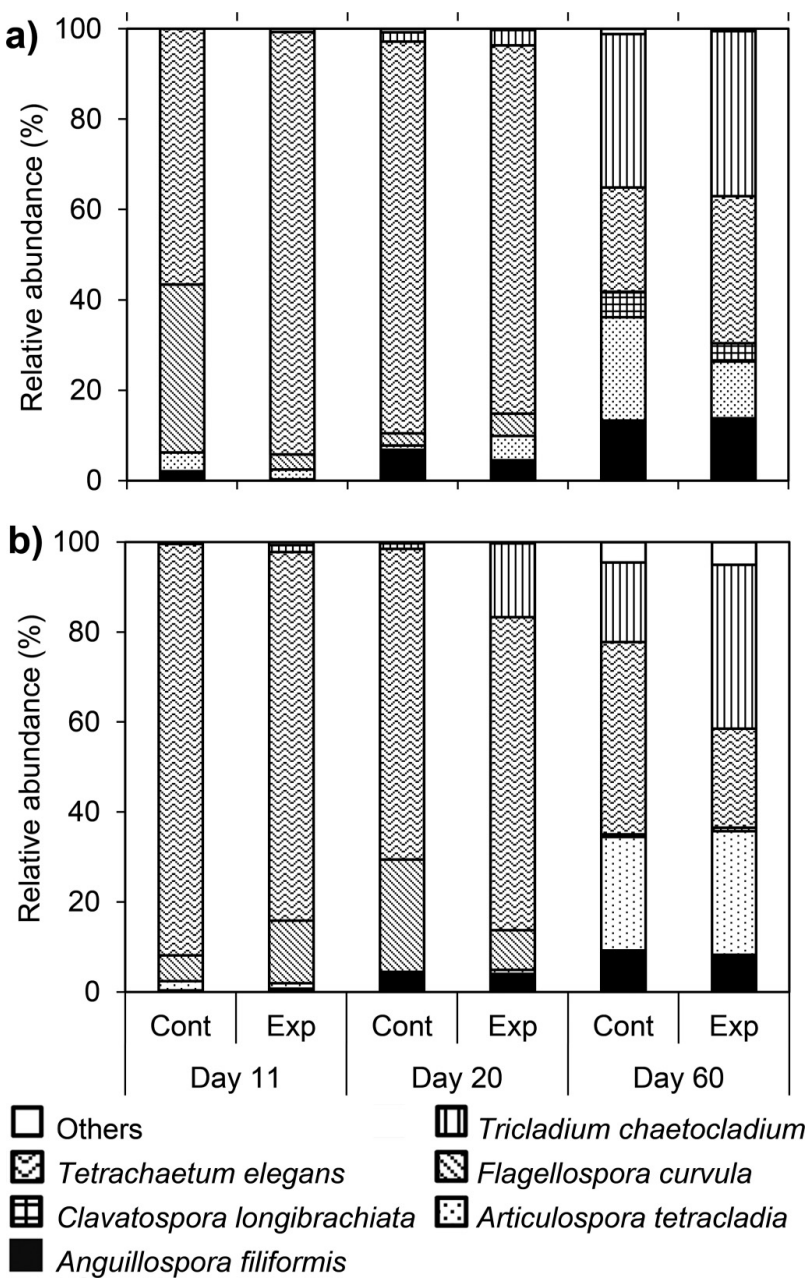

chestnut incubated in the control half than in the other three treatments (Fisher's test, $P<0.038$; Fig. $5 c$ ).

Shredder communities were distinct between both litter species (ANOSIM, global $R=0.236, P=0.026$ ); individuals were more evenly distributed by taxa in chestnut than in oak. Nemoura sp. and the two species of Scirtidae beetles were only present in oak, while Allogamus laureatus and Lepidostoma hirtum only appeared in chestnut (Fig. 6). Neither water temperature (ANOSIM, $P=0.065$ ) nor time $(P=0.296)$ seemed to play a major role in shaping shredder community structure.

\section{Discussion}

Manipulation of warming at the stream level

In this study, we experimentally increased the water temperature by $2.8^{\circ} \mathrm{C}$ in one half of a small mountain stream that was divided longitudinally to assess the effects of global warming on the decomposition of two litter species in the presence and absence of macroinvertebrates. This study makes several advances in the assessment of the effects of global warming in stream ecosystems. First, by experimentally manipulating water temperature in a small mountain stream, it addresses the effects of warming at the ecosystem level under realistic environmental conditions while controlling for factors associated with water chemistry and biogeography. The manipulation of temperature of surface flowing waters has been undertaken only once, and it allowed insight into the effects of global warming on aquatic macroinvertebrates' population dynamics (Hogg et al. 1995; Hogg and Williams 1996). The continuous heating of flowing water presents several challenges, primarily related with the huge amount of energy required (constant supply of $42 \mathrm{~kW}$ in this study), which is often not available in remote areas where nearpristine streams can be found, and with the large costs associated with the maintenance of the system. This explains why such an approach has not been attempted more often and the lack of replication when it has been performed (unfortunately, also in this study). One strategy to improve the predictive power of unreplicated study designs is to use a BACI design (Smith 2002). However, this was not possible in our case, since we were spacelimited (several experiments took place simultaneously in the experimental small stream reach). These design limitations result in low statistical power and thus restricted our ability to detect an effect of warming. Thus, the effects of warming in this study can be seen as highly conservative.

Second, this study evaluates the effects of warming on litter decomposition, together with changes in litter species identity and in shredder presence. Since leaf litter from distinct species differ in physical and chemical characteristics (Ostrofsky 1997), 
Fig. 5. (a) Total macroinvertebrate abundance, (b) shredder abundance, and (c) shredder taxa richness associated with oak and chestnut leaf litter incubated in coarse mesh bags in the control and experimental half over 60 days. Values are means \pm SE.
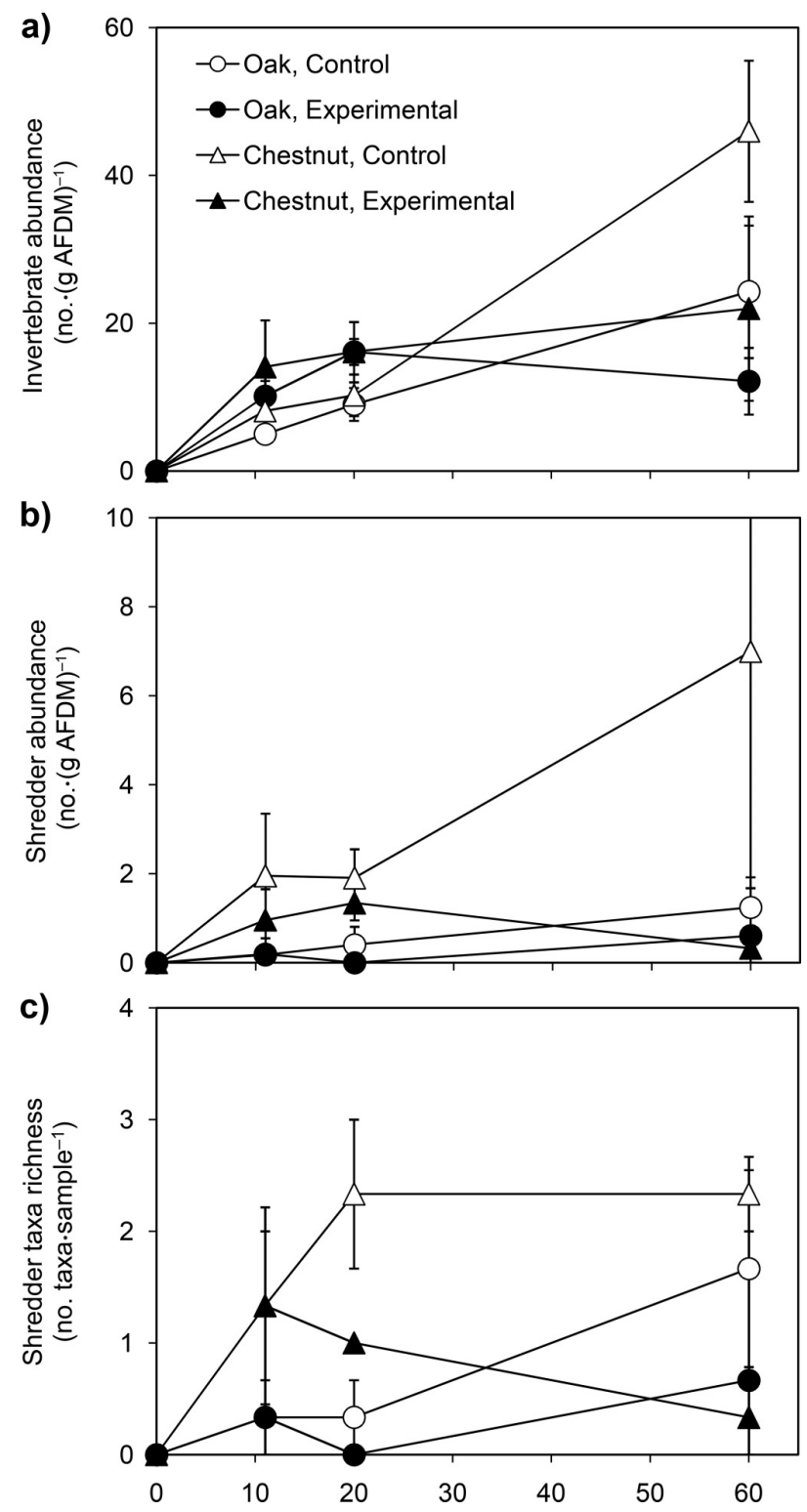

and decomposers and shredders have substrate preferences (Canhoto and Graça 1996; Gulis 2001; Gonçalves et al. 2013), the decomposition of different litter species might be distinctly susceptible to warming (Rouifed et al. 2010; Gonçalves et al. 2013). The evaluation of the interaction between increases in water temperature and changes in litter species on litter decomposition is increasingly relevant if we take into account the predictions from models simulating future species distribution that suggest a change in the range and area occupied by tree species (Bakkenes et al. 2002), including the common European woodland species Q. robur and C. sativa used in this study (Benito Garzón et al. 2008) Also, most shredder species belong to the orders Plecoptera and Trichoptera, which evolve in cold environments, have low upper thermal tolerance limits, and can be therefore negatively affected by increases in temperature (Gaufin and Hern 1971; Pearson and
Fig. 6. Relative contribution of shredder taxa to the total shredder abundance associated with $(a)$ oak and $(b)$ chestnut leaf litter incubated in coarse mesh bags in the control (Cont) and experimental (Exp) half over 60 days.
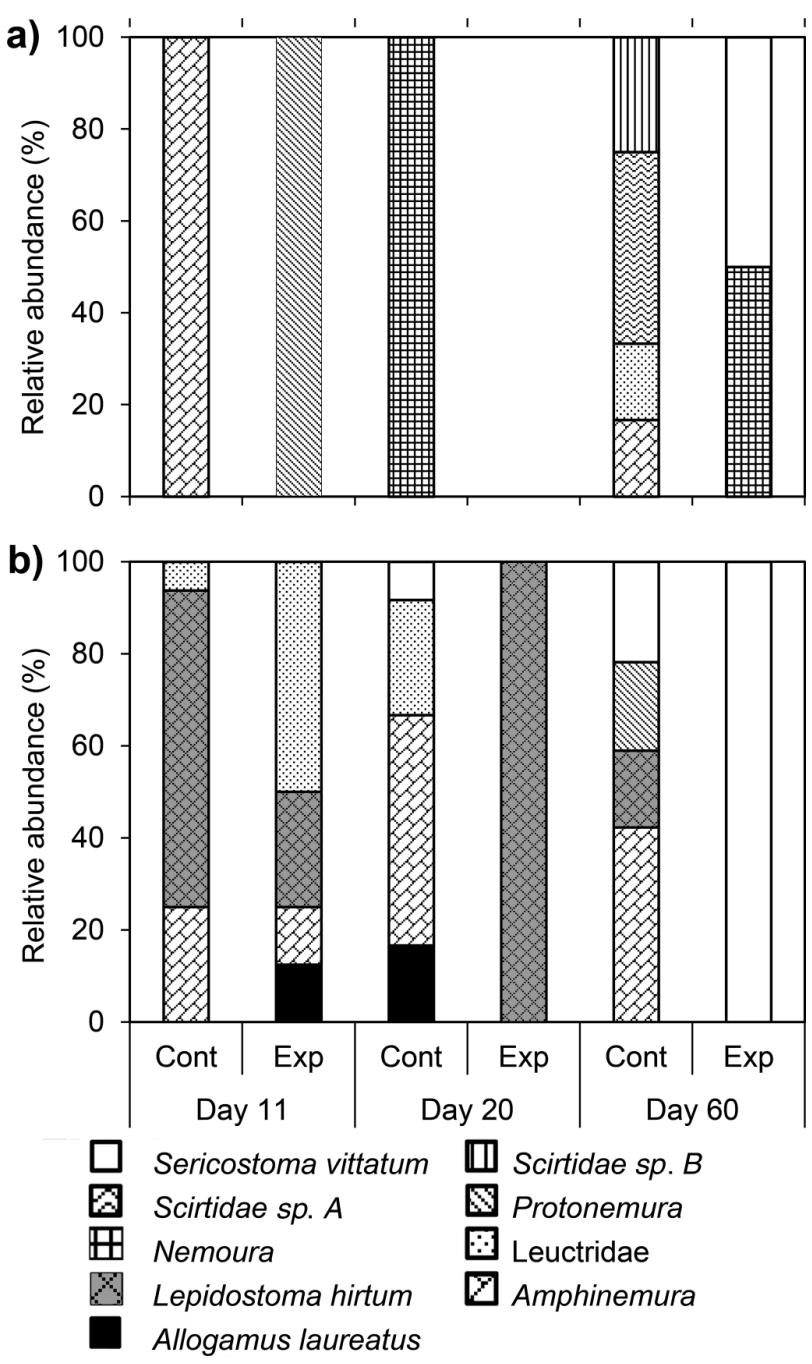

Boyero 2009). Additionally, the sensitivity of shredders' activities to temperature might depend on litter species (González and Graç 2003). The simultaneous evaluation of the effects of warming, changes in litter species, and presence of shredders on litter decomposition increased our ability to foresee future effects of climate change on the functioning of small headwater streams. We found that the increase in water temperature generally stimulated litter decomposition; however, the extent and significance of this stimulation depended on the litter species and presence of macroinvertebrates.

\section{Effect of litter species on litter decomposition}

Leaf litter decomposition was faster for chestnut than for oak, which agrees with previous studies (Ferreira et al. 2012). In our case, the difference in decomposition rate between litter species can be attributed to chestnut leaves being softer than oak leaves; leaf toughness has been shown to be a primary determinant of biological colonization and decomposition of leaf litter (Li et al. 2009; Graça and Cressa 2010). The initially higher P concentration in oak than in chestnut probably did not have any effect on litter decomposition, since it leached rapidly, and after day 11 (and prob- 
ably before), a similar P concentration in both litter species was determined. The difference between litter species was the highest for overall litter decomposition in the control half $(78 \%$ versus $37 \%-40 \%$ in the other three situations), which can be attributed to the higher shredder abundance and species richness associated with chestnut than with oak under ambient temperature. Overall, the magnitude of differences in decomposition between litter species depended on the presence of macroinvertebrates and on water temperature.

\section{Effect of macroinvertebrate presence on litter decomposition}

Litter decomposition was generally faster in the presence of macroinvertebrates (coarse mesh bags) than in their absence (fine mesh bags), which was not surprising (Cuffney et al. 1990; Stewart 1992). However, macroinvertebrates were relatively weak contributors to overall litter decomposition; decomposition attributed to invertebrate activity was only $23 \%-37 \%$ of litter decomposition, being highest for chestnut incubated at ambient temperature because of higher colonization by shredders. These results are in agreement with a recent study that also reported a relatively low contribution of invertebrates (9\%-29\%), compared with microbes, to litter decomposition (Taylor and Chauvet 2014). In our case, the number of shredders colonizing decomposing litter was globally low, which can explain why litter decomposition was only $29 \%$ $59 \%$ faster in coarse than in fine mesh bags. These results contrast with those from previous studies in the same stream, where chestnut litter decomposed 218\% faster (Ferreira et al. 2012) and oak litter decomposed $166 \%$ faster in coarse than in fine mesh bags (Gulis et al. 2006). In both studies, however, litter was incubated further upstream, in the main channel where colonization by invertebrates might have been more effective and mass loss from coarse mesh bags might have been also promoted by physical abrasion, especially during high flow periods; in our study site, flow was continuously kept at $2.3 \mathrm{~L} \cdot \mathrm{s}^{-1}$ and physical fragmentation of leaf litter was probably negligible (Ferreira et al. 2006).

\section{Effect of warming on litter decomposition}

The temperature effect on litter decomposition was similar in both litter species in fine mesh bags (34\% in chestnut and 38\% in oak), suggesting that stimulation of microbial-driven litter mass loss was independent of litter species, despite sporulation by aquatic hyphomycetes being stimulated in chestnut, but not in oak, under warmer conditions. Warming significantly stimulated decomposition of oak in coarse mesh bags (49\%), indicating that invertebrate activity in oak litter was the most responsive to warming, in spite of no significant difference in the number of shredders associated with these leaves between stream halves. Warming also significantly stimulated decomposition of chestnut in fine mesh bags (34\%), which can be attributed to the increased fungal activity under elevated temperature. Surprisingly, the decomposition of chestnut litter in coarse mesh bags was the least sensitive to warming (only 15\% faster than in the control half), indicating that invertebrate activity in chestnut was inhibited by the increase in temperature, probably as a reflex of the decrease in the number of shredders in chestnut under warmer conditions. These results must, however, be taken conservatively owing to low statistical power. Although temperature sensitivity of litter decomposition was higher for the tough oak, when considering a $10{ }^{\circ} \mathrm{C}$ increase in temperature, both litter species decompose at similar rates, because oak decomposes more slowly than chestnut at ambient temperature.

Relative importance of litter species, invertebrate presence, and warming on litter decomposition

According to our results, the three factors under study can be ranked regarding their relative importance on litter decomposition as follows: litter species > invertebrate presence > tempera- ture. This hierarchical arrangement is partially in agreement with that proposed by Aerts (2006) for litter decomposition in terrestrial systems: climate (temperature $\times$ moisture) $>$ litter quality $>$ soil invertebrates. The difference in the relative importance of temperature between studies is explained by differences in study scale; our study was performed in a single stream reach, while Aerts (2006) reports results from 34 site-species combinations. The hierarchy of factors found in our study suggests that the effects of an increase in temperature by up to $3^{\circ} \mathrm{C}$ on litter decomposition might be smaller than those promoted by changes in riparian vegetation composition or in the activity and (or) abundance of invertebrates (Rouifed et al. 2010). However, changes in these factors might enhance the effects of temperature increase on litter decomposition. The composition of the riparian vegetation and abundance or activity of invertebrates can change as a direct effect of climate change (Hogg and Williams 1996; Bakkenes et al. 2002; Friberg et al. 2009) or as a result from anthropogenic activities, which might be intensified under climate change scenarios (e.g., intensification of agricultural practices). The relative importance of temperature on litter decomposition might be expected to rise if increases in temperature go beyond $3{ }^{\circ} \mathrm{C}$ or if the availability of dissolved nutrients is high (Marcarelli and Wurtsbaugh 2006; Ferreira and Chauvet 2011a).

\section{Effect of warming on biological colonization}

Warming did not affect fungal biomass accumulation in either litter species. This might be attributed to low magnitude of the experimental warming $\left(2.8^{\circ} \mathrm{C}\right.$; Ferreira and Chauvet 2011a, 2011b) to nutrient limitation for fungal growth due to the stream oligotrophic status (Ferreira and Chauvet 2011a) or to low statistical power.

Warming distinctly affected sporulation by aquatic hyphomycetes between litter species, with stimulation in chestnut but not in oak. Additionally, warming led to differences between litter species that did not exist in the control half. The stimulation of fungal sporulation rate by $2.8^{\circ} \mathrm{C}$ warming was expected, since the ambient water temperature was relatively low $\left(6.4^{\circ} \mathrm{C}\right)$ (Ferreira and Chauvet 2011a, 2011b). In our study, conidial production in the tough oak litter was not sensitive to warming, which together with its stimulation in the soft chestnut litter here and alder (Alnus glutinosa) litter in previous studies (Ferreira and Chauvet 2011a, 2011b) might suggest that litter toughness is an important determinant of the response of fungal reproductive activity to temperature increase.

Despite the stimulation of fungal conidial production in chestnut incubated in the experimental half, no effect of temperature was found on the structure of aquatic hyphomycete communities for any litter species, suggesting that warming stimulated most fungal species to a similar degree. This contrasts with previous studies that reported marked changes in community structure with warming (Bärlocher et al. 2008; Dang et al. 2009; Ferreira and Chauvet 2011a, 2011b; Gonçalves et al. 2013). The difference in the response of community structure to warming between our study and previous studies can probably be explained by the smaller temperature increase tested here $\left(2.8\right.$ versus $4.3-10^{\circ} \mathrm{C}$ in previous studies). Larger temperature increases would likely favor warmwater species as Lunulospora curvula (observed in the study stream during spring) and inhibit cold-water species as F. curvula. Incubation time was the most important factor ruling fungal community structure, which is not surprising giving that fungal species colonize decomposing substrata following an ecological succession, which parallels the physical and chemical changes occurring in the submerged litter over the decomposition process (Gessner et al. 1993). Litter species also contributed to shape fungal communities, mostly with respect to the presence and abundance of rare species, which can be attributed to substrate preferences (Thomas et al. 1992; Gulis 2001; but see Nikolcheva and Bärlocher 2005). 
Contrary to the effect of warming on fungal communities, the increase in temperature mitigated the differences in shredders colonization that existed between litter species in the control half through a decrease in the abundance and richness of shredders associated with chestnut litter in the experimental half. Previous studies have reported reduced abundance of benthic invertebrates under warmer conditions (Hogg et al. 1995; Hogg and Williams 1996; Durance and Ormerod 2007). However, no effect of temperature was found on the structure of shredder communities associated with decomposing litter.

\section{Relevance for stream bioassessment}

The absence of an effect of warming by $2.8^{\circ} \mathrm{C}$ on communities structure associated with decomposing litter might suggest that changes in function can occur without major changes in structure. This has strong implications for biomonitoring programs that evaluate ecosystem health based on the assessment of struc tural aspects of aquatic communities (e.g., European Water Framework Directive (Directive 2000/60/EC 2000), US Clean Water Act (CWA 33 USC Section 1251 et seq. 1972)). If ecosystem processes can be affected by warming without substantial changes to the aquatic communities, then evaluating the effects of climate change on ecosystem integrity based solely on the assessment of structural parameters might be misleading.

\section{Repercussion on global C cycle}

The stimulated litter decomposition under future climate change scenarios can lead to increases in the amount of $\mathrm{C}$ returned to the atmosphere and to a faster disappearance of litter from the stream bed, which has the potential to lead to a mismatch between consumers and their resources (Durant et al 2007). However, oak litter decomposition is naturally slow (484 days to lose 95\% initial mass in the presence of invertebrates under ambient temperature estimated in this study), and therefore a $49 \%$ stimulation of the decomposition rate might still allow oak litter to remain in the stream over the year, until the next litter fall period. Food shortage might occur, however, in streams that are supplied with fast-decomposing litter species (e.g., alder, maple) or have higher dissolved nutrient concentration, where a stimulation of litter decomposition can lead to the disappearance of litter from the stream bed well before the next autumnal litter fall. Long-term studies are necessary to evaluate possible consequences of faster litter decomposition on stream food webs.

In summary, this study shows that the effect of warming in stream ecosystems is complex and cannot be easily anticipated. The effect of warming on litter decomposition depended on litter species and presence of macroinvertebrates, which suggests that interactions between increases in temperature and changes in other factors must be taken into account when modeling the future effect of global warming on ecosystem functioning.

The relative importance of the three factors under study on litter decomposition can be ranked as follows: litter species $>$ invertebrate presence $>$ temperature. Nevertheless, even small increases in temperature can produce noticeable effects in ecosystem processes if these interact with changes in other factors, as likely occurs under field conditions.

Warming did not significantly affect the community structure of aquatic hyphomycetes or detritivores associated with decomposing litter, which suggests that aquatic communities are more resistant to environmental changes than ecosystem-level processes. Thus, ecosystem-level processes should be considered when evaluating the effect of changes in environmental factors on ecosystem integrity.

Stimulation of litter decomposition under future scenarios may not strongly affect aquatic communities in streams where slowdecomposing litter (e.g., oak) prevails, as enough litter may still remain in the system until the following litter fall. However, fast decomposition of high-quality (low C:N) soft litter may lead to a mismatch between consumers and resources and to food depletion for aquatic communities during part of the year. Thus, the presence of slow-decomposing litter species in the riparian vegetation may contribute to mitigate the effect of warming on stream ecosystem functioning.

\section{Acknowledgements}

Cristina Docal performed the ion chromatography and HPLC analyses, Ana Lírio and João Rosa helped in the field, Amado and Amado Company built and maintained the warming system, and the Lousã Town Hall provided logistic support. José Paulo Sousa (University of Coimbra) provided useful advice on the statistical analyses, and the comments provided by two anonymous referees greatly improved the manuscript. This study was financed by the IMAR-CMA, the FEDER European Funds through the Program Operational Factors of Competitiveness (COMPETE) and national funds through the Portuguese Science and Technology Foundation (FCT, project PTDC/CLI/67180/2006), and the French EC2CO (Continental and Coastal Ecosphere) CNRS program to the Interhym project. Financial support was also granted by the FCT to VF (postdoctoral fellowships SFRH/BPD/34368/2006 and SFRH/BPD/ 76482/2011, program POPH/FSE) and by the Pessoa exchange program between Portugal and France (PHC 22808TB) from the French Ministry of Foreign and European Affairs.

\section{References}

Aerts, R. 2006. The freezer defrosting: global warming and litter decomposition rates in cold biomes. J. Ecol. 94: 713-724. doi:10.1111/j.1365-2745.2006.01142.x. Allan, J.D., and Castillo, M.M. 2007. Stream ecology. Structure and function of running waters. Springer, Dordrecht.

APHA. 1995. Standard methods for the examination of water and wastewater. American Public Health Association, Washington, D.C.

Bakkenes, M., Alkemade, J.R.M., Ihle, F., Leemans, R., and Latour, J.B. 2002 Assessing effects of forecasted climate change on the diversity and distribution of European higher plants for 2050. Global Change Biol. 8: 390-407. doi:10.1046/j.1354-1013.2001.00467.x.

Bärlocher, F., Seena, S., Wilson, K.P., and Williams, D.D. 2008. Raised water temperature lowers diversity of hyporheic aquatic hyphomycetes. Freshw. Biol. 53: 368-379. doi:10.1111/j.1365-2427.2007.01899.

Battin, T.J., Kaplan, L.A., Findlay, S., Hopkinson, C.S., Marti, E., Packman, A.I. Newbold, J.D., and Sabater, F. 2008. Biophysical controls on organic carbon fluxes in fluvial networks. Nat. Geosci. 1: 95-100. doi:10.1038/ngeo101.

Benito Garzón, M., Sánchez de Dios, R., and Sainz Ollero, H. 2008. Effects of climate change on the distribution of Iberian tree species. Appl. Veg. Sci. 11: 169-178, doi:10.3170/2008-7-18348.

Berbeco, M.R., Melillo, J.M., and Orians, C.M. 2012. Soil warming accelerates decomposition of fine woody debris. Plant Soil, 356: 405-417. doi:10.1007| s11104-012-1130-x.

Boyero, L., Pearson, R.G., Gessner, M.O., Barmuta, L.A., Ferreira, V., Graça, M.A.S . Dudgeon, D., Boulton, A.J., Callisto, M., Chauvet, E., Helson, J.E., Bruder, A. Albariño, R.J., Yule, C.M., Arunachalam, M., Davies, J.N., Figueroa, R., Flecker, A.S., Ramírez, A., Death, R.G., Iwata, T., Mathooko, J.M. Mathuriau, C., Gonçalves, J.F., Jr., Moretti, M.S., Jinggut, T., Lamothe, S., M'Erimba, C., Ratnarajah, L., Schindler, M.H., Castela, J., Buria, L.M., Cornejo, A., Villanueva, V.D., and West, D.C. 2011. A global experiment suggests climate warming will not accelerate litter decomposition in stream but might reduce carbon sequestration. Ecol. Lett. 14: 289-294. doi:10.1111/j. 1461-0248.2010.01578.x. PMID:21299824.

Brown, J.H., Gillooly, J.F., Allen, A.P., Savage, V.M., and West, G.B. 2004. Toward a metabolic theory of ecology. Ecology, 85: 1771-1789. doi:10.1890/03-9000.

Buzby, K.M., and Perry, S.A. 2000. Modeling the potential effects of climate change on leaf pack processing in central Appalachian streams. Can. J. Fish. Aquat. Sci. 57(9): 1773-1783. doi:10.1139/f00-113.

Canhoto, C., and Graça, M.A.S. 1996. Decomposition of Eucalyptus globulus leaves and three native leaf species (Alnus glutinosa, Castanea sativa and Quercus faginea) in a Portuguese low order stream. Hydrobiologia, 333: 79-85. doi:10. 1007/BF00017570

Canhoto, C., Lima, J.L.M.P., and de Almeida, A.T. 2013. Warming up a stream reach: design of a hydraulic and heating system. Limnol. Oceanogr. Methods, 11: 410-417. doi: $10.4319 / \mathrm{lom} 2013.11 .410$.

Chauvet, E., and Suberkropp, K. 1998. Temperature and sporulation of aquatic hyphomycetes. Appl. Environ. Microbiol. 64: 1522-1525. PMID:16349551.

Cole, J.J., Prairie, Y.T., Caraco, N.F., McDowell, W.H., Tranvik, L.J., Striegl, R.G. Duarte, C.M., Kortelainen, P., Downing, J.A., Middelburg, J.J., and Melack, J. 2007. Plumbing the global carbon cycle: integrating inland waters into the terrestrial carbon budget. Ecosystems, 10: 171-184. doi:10.1007/s10021-0069013-8. 
Conant, R.T., Drijber, R.A., Haddix, M.L., Parton, W.J., Paul, E.A., Plante, A.F. Sixs, J., and Steinweg, J.M. 2008. Sensitivity of organic matter decomposition to warming varies with its quality. Global Change Biol. 14: 868-877. doi:10. $1111 / \mathrm{j} .1365-2486.2008 .01541 . x$

Cuffney, T.F., Wallace, J.B., and Lugthart, G.J. 1990. Experimental evidence quantifying the role of benthic invertebrates in organic matter dynamics of headwater streams. Freshw. Biol. 23: 281-299. doi:10.1111/j.1365-2427.1990. tb00272.x.

CWA 33 USC Section 1251 et seq. 1972. Federal water pollution control act. 2nd United States Congress on the 18th October 1972

Dang, C.K., Schindler, M., Chauvet, E., and Gessner, M.O. 2009. Temperature oscillation coupled with fungal community shifts can modulate warming effects on litter decomposition. Ecology, 90: 122-131. doi:10.1890/07-1974.1.

Directive 2000/60/EC. 2000. Water Framework Directive of the European Parliament and the Council, of 23 October 2000, establishing a framework for Community action in the field of water policy. Official Journal of the European Communities, L327: 1-72.

Durance, I., and Ormerod, S.J. 2007. Climate change effects on upland stream macroinvertebrates over a 25-year period. Global Change Biol. 13: 942-957. doi:10.1111/j.1365-2486.2007.01340.x.

Durant, J.M., Hjermann, D.Ø., Ottersen, G., and Stenseth, N.C. 2007. Climate and the match or mismatch between predator requirements and resource availability. Clim. Res. 33: 271-283. doi:10.3354/cr033271.

Fabre, E., and Chauvet, E. 1998. Leaf breakdown along an altitudinal stream gradient. Arch. Hydrobiol. 141: 167-179.

Fernandes, I., Pascoal, C., Guimarães, H., Pinto, R., Sousa, I., and Cássio, F. 2012 Higher temperature reduces the effects of litter quality on decomposition by aquatic fungi. Freshw. Biol. 57: 2306-2317. doi:10.1111/fwb.12004.

Ferreira, V., and Chauvet, E. 2011a. Synergistic effects of water temperature and dissolved nutrients on litter decomposition and associated fungi. Global Change Biol. 17: 551-564. doi:10.1111/j.1365-2486.2010.02185.x.

Ferreira, V., and Chauvet, E. 2011b. Future increase in temperature more than decrease in litter quality can affect microbial litter decomposition in streams. Oecologia, 167: 279-291. doi:10.1007/s00442-011-1976-2.

Ferreira, V., Graça, M.A.S., de Lima, J.L.M.P., and Gomes, R. 2006. Role of physical fragmentation and invertebrate activity in the breakdown rate of leaves. Arch. Hydrobiol. 165: 493-513. doi:10.1127/0003-9136/2006/0165-0493.

Ferreira, V., Encalada, A.C., and Graça, M.A.S. 2012. Effects of litter diversity on decomposition and biological colonization of submerged litter in temperate and tropical streams. Freshw. Sci. 32: 945-962. doi:10.1899/11-062.1.

Friberg, N., Dybkaer, J.B., Olafsson, J.S., Gislason, G.M., Larsen, S.E., and Laridsen, T.L. 2009. Relationships between structure and function in stream contrasting in temperature. Freshw. Biol. 5: 2051-2068. doi:10.1111/j.13652427.2009.02234.x

Gaufin, A.R., and Hern, S. 1971. Laboratory studies on tolerance of aquatic insects to heated waters. J. Kansas Entomol. Soc. 44: 240-245.

Gessner, M.O., and Chauvet, E. 1993. Ergosterol-to-biomass conversion factors for aquatic hyphomycetes. Appl. Environ. Microbiol. 59: 502-507. PMID 16348874 .

Gessner, M.O., and Chauvet, E. 1994. Importance of stream microfungi in controlling breakdown rates of leaf litter. Ecology, 75: 1807-1817. doi:10.2307| 1939639.

Gessner, M.O., Thomas, M., Jean-Louis, A.-M., and Chauvet, E. 1993. Stable successional patterns of aquatic hyphomycetes on leaves decaying in a summer cool stream. Mycol. Res. 97: 163-172. doi:10.1016/S0953-7562(09)80238-4.

Gessner, M.O., Chauvet, E., and Dobson, M. 1999. A perspective on leaf litter breakdown in streams. Oikos, 85: 377-383 doi:10.2307/3546505.

Gonçalves, A.L., Graça, M.A.S., and Canhoto, C. 2013. The effect of temperature on leaf decomposition and diversity of associated aquatic hyphomycete depends on the substrate. Fungal Ecol. 6: 546-553. doi:10.1016/j.funeco.2013 07.002 .

González, J.M., and Graça, M.A.S. 2003. Conversion of leaf litter to secondary production by a shredding caddis-fly. Freshw. Biol. 48:1578-1592. doi:10.1046| j.1365-2427.2003.01110.x.

Gore, J.A. 1996. Discharge measurements and streamflow analysis. In Methods in stream ecology. Edited by F.R. Hauer and G.A. Lamberti. Academic Press, San Diego, Calif. pp. 53-74.

Graça, M.A.S., and Cressa, C. 2010. Leaf quality of some tropical and temperate tree species as food resource for stream shredders. Int. Rev. Hydrobiol. 95: 27-41. doi:10.1002/iroh.200911173.

Graça, M.A.S., Bärlocher, F., and Gessner, M.O. 2005. Methods to study litter decomposition. A practical guide. Springer, Dordrecht.

Gulis, V. 2001. Are there any substrate preferences in aquatic hyphomycetes? Mycol. Res. 105: 1088-1093. doi:10.1016/S0953-7562(08)61971-1.

Gulis, V., Ferreira, V., and Graça, M.A.S. 2006. Stimulation of leaf litter decomposition and associated fungi and invertebrates by moderate eutrophication: implications for stream assessment. Freshw. Biol. 51: 1655-1669. doi:10.1111 j.1365-2427.2006.01615 x

Hogg, I.D., and Williams, D.D. 1996. Response of stream invertebrates to a globalwarming thermal regime: an ecosystem-level manipulation. Ecology, 77: 395-407. doi:10.2307/2265617.

Hogg, I.D., Williams, D.D., Eadie, J.M., and Butt, S.A. 1995. The consequences of global warming for stream invertebrates: a field simulation. J. Therm. Biol. 20: 199-206. doi:10.1016/0306-4565(94)00057-P.

IPCC. 2013. Summary for policymakers. In Climate change 2013: The physical science basis. Contribution of the Working Group I to the Fifth Assessment Report of the Intergovernmental Panel on Climate Change. Edited by T.F. Stocker, D. Qin, G.-K. Plattner, M. Tignor, S.K. Allen, J. Boschung, A. Nauels, Y. Xia, V. Bex, and P.M. Midgley. Cambridge University Press Cambridge, UK, and New York, N.Y

Irons, J.G., Oswood, M.W., Stout, R.J., and Pringle, C.M. 1994. Latitudinal pattern in leaf litter breakdown: is temperature really important? Freshw. Biol. 32: 401-411. doi:10.1111/j.1365-2427.1994.tb01135.x.

Li, A.O.Y., Ng, L.C.Y., and Dudgeon, D. 2009. Effects of leaf toughness and nitrogen content on litter breakdown and macroinvertebrates in a tropical streams. Aquat. Sci. 71: 80-93. doi:10.1007/s00027-008-8117-y.

Marcarelli, A.M., and Wurtsbaugh, W.A. 2006. Temperature and nutrient supply interact to control nitrogen fixation in oligotrophic streams: an experimental examination. Limnol. Oceanogr. 51: 2278-2289. doi:10.4319/lo.2006.51.5. 2278.

Miranda, P., Coelho, F.E.S., Tomé, A.R., and Valente, M.A. 2002. 20th century Portuguese climate and climate scenarios. In Climate change in Portugal. Scenarios, impacts and adaptation measures. SIAM Project. Edited by F.D. Santos, K. Forbes, and R. Moita. Gradiva Publications, Lda, Lisbon. pp. 23-83.

Morrill, J.C., Bales, R.C., and Conklin, M.H. 2005. Estimating stream temperature from air temperature: implications for future water quality. J. Environ. Eng. 131: 139-146. doi:10.1061/(ASCE)0733-9372(2005)131:1(139).

Nikolcheva, L.G., and Bärlocher, F. 2005. Seasonal and substrate preferences of fungi colonizing leaves in streams: traditional versus molecular evidence. Environ. Microbiol. 7: 270-280. doi:10.1111/j.1462-2920.2004.00709.x. PMID 15658994.

Ostrofsky, M.L. 1997. Relationship between chemical characteristics of autumnshed leaves and aquatic processing rates. J. N. Am. Benthol. Soc. 16: 750-759. doi:10.2307/1468168.

Parmesan, C., and Yohe, G. 2003. A globally coherent fingerprint of climate change impacts across natural systems. Nature, 421: 37-42. doi:10.1038| nature01286. PMID:12511946.

Pearson, R.G., and Boyero, L. 2009. Gradients in regional diversity of freshwater taxa. J. N. Am. Benthol. Soc. 28: 504-514. doi:10.1899/08-118.1.

Pilgrim, J.M., Fang, X., and Stefan, H.G. 1998. Stream temperature correlations with air temperatures in Minnesota: implications for climate warming. J. Am. Water Resour. Assoc. 34: 1109-1121. doi:10.1111/j.1752-1688.1998.tb04158.x.

Rouifed, S., Handa, I.T., David, J.-F., and Hättenschwiler, S. 2010. The importance of biotic factors in predicting global change effects on decomposition of temperate forest leaf litter. Oecologia, 163: 247-256. doi:10.1007/s00442-0091528-1. PMID:20033823.

Smith, E.P. 2002. BACI design. In Encyclopidia of environmetrics. Edited by A.H. El-Shaarawi and W.W. Piegorsch. Wiley, Ltd., Chichester. pp. 141-148.

Stewart, B.A. 1992. The effect of invertebrates on leaf decomposition rates in two small woodland streams in southern Africa. Arch. Hydrobiol. 124: 19-33.

Tachet, H., Richoux, P., Bournaud, M., and Usseglio-Polatera, F. 2010. Invertébrés d'eau douce. Systématique, biologie, écologie. CNRS Éditions, Paris.

Taylor, B.R., and Chauvet, E. 2014. Relative influence of shredders and fungi on leaf litter decomposition along a river altitudinal gradient. Hydrobiologia, 721: 239-250. doi:10.1007/s10750-013-1666-7.

Thomas, K., Chilvers, G.A., and Norris, R.H. 1992. Aquatic hyphomycetes from different substrates: substrate preference and seasonal occurrence. Aust. J. Mar. Freshw. Res. 43: 491-509. doi:10.1071/MF9920491.

Thormann, M.N., Bayley, S.E. and Currah, R.S. 2004. Microcosm tests of the effects of temperature and microbial species number on the decomposition of Carex aquatilis and Sphagnum fuscum litter from southern boreal peatlands. Can. J. Microbiol. 50(10): 793-802. doi:10.1139/w04-064. PMID:15644893.

Traill, L.W., Lim, M.L.M., Sodhi, N.S., and Bradshaw, C.J.A. 2010. Mechanisms driving change: altered species interactions and ecosystem function through global warming. J. Anim. Ecol. 79: 937-947. doi:10.1111/j.1365-2656.2010. 01695.x. PMID:20487086.

Vannote, R.L., Minshall, G.W., Cummins, K.W., Sedall, J.R., and Cushing, C.E. 1980. The river continuum concept. Can. J. Fish. Aquat. Sci. 37(1): 130-137. doi:10.1139/f80-017.

Woodward, G., Perkins, D.M., and Brown, L.E. 2010. Climate change and freshwater ecosystems: impacts across multiple levels of organization. Philos. Trans. R. Soc. B Biol. Sci. 365: 2093-2106. doi:10.1098/rstb.2010.0055. PMID: 20513717. 